\title{
The Role of Agricultural Cooperatives in Agricultural Development in Ethiopia
}

\author{
Michael Senbeta Feyisa PhD Candidate \\ Ambo University: Institute of Cooperatives and Development Studies, Department of Cooperative Studies
}

\begin{abstract}
Agricultural cooperatives have played an important role in the Ethiopian rural landscape for decades, and have become an integral part of its social structure and it is a significant form of business enterprise. The review aims to explore the role of agricultural cooperatives in agriculture development to reduce poverty in Ethiopia. The study is based on review of pertinent literature on agricultural cooperatives in Ethiopia as well as secondary data obtained from various sources. The review identified the contributions of agricultural cooperatives in agricultural development, which contribute to the rural development and the challenges facing the sector. Finally; the study suggested promoting agricultural cooperatives among the rural areas can increase development in agriculture to alleviate rural poverty in developing countries in general and Ethiopia in particular.
\end{abstract}

Keywords: Agricultural Cooperative, Agriculture Development, Poverty Reduction, Rural Development

DOI: $10.7176 / \mathrm{DCS} / 10-5-01$

Publication date:May $31^{\text {st }} 2020$

\section{Introduction}

Cooperatives are a business owned and controlled by the people to meet peoples' common requirements. They finance and operate the business for their mutual benefit. This implies they are created on the leading idea that by working together, a group of people can achieve an objective that would be unattainable if acting alone (Ruhul \& Mahin, 2014; Desalegn, 2019).

Of the many types of cooperatives, agricultural cooperatives play dominant role in the socio-economic development of countries. Cooperatives have been established to offset the problems of market failure, particularly all small scale farmers all over the world. As cited in Agnes (2011), cooperatives help to grant farmers with access to markets and build up their bargaining power. Due to this fact, the international institutions, the governments and Non-governmental organizations are supporting agricultural cooperatives and cooperative unions' development as a juncture for empowering helpless male and female smallholder farmers to shielded sustainable livelihoods.

The following are some of the definitions given for agriculture and agricultural cooperatives by different authors: RUWA (1968), defined agriculture as farming in all its branches and among other things includes the cultivation and tillage of the soil, dairying, production, cultivation, growing, and harvesting of any agricultural or horticultural commodities, the raising of livestock or poultry, and any practices performed by a farmer on a farm as an incident to or in conjunction with some farming operations, but does not include the farm products. According to Vienney (1980), Agricultural cooperatives are defined as groups of farmers mutually linked in the corporation, which they form and whose services they reward themselves of, in a double relationship of active participation and full membership. Their principal activity is not agriculture, as might be predicted from their title, but it is the farmers' concerted use of the means at their disposal to accelerate and improve their economic activities.

Agricultural production cooperative described as a farm where, the land and major capital items are held in joint ownership by the farm workers themselves, the bulk of the land is collectively cultivated, and any profits of the enterprise are shared by the cooperative members. Ideally, as joint owners, members of production cooperatives participate in the decision-making process concerning all aspects of production, distribution and investment (Chibanda et al, 2009).

Consequently, the review aims at exploring the role of agricultural cooperatives in agriculture development to reduce poverty and identifying the major challenges facing the sector in Ethiopia.

\section{Methods}

The study is based on review of pertinent literature on agricultural cooperatives in Ethiopia as well as secondary data obtained from various source including Google scholar. Moreover, past study reports and cooperatives periodic activity reports, Federal Cooperative Proclamation No 147/1998 and Cooperative Societies (Amendment) Proclamation No. 402/2004. The most prominent secondary data were obtained from the Federal Cooperative Agency of the country.

\section{Types of Agricultural Cooperatives}

Agricultural cooperatives are normally categorized according to the three major functions they perform. According to Mather et al (1998), many agricultural cooperatives combine the three types of functions (such as marketing, 
supply and service) in their operations. Marketing cooperatives are cooperatives that help to sell their members' farm products and maximize the return that they receive for these goods. Their operations can be quite diversified and complex as some perform a few number of functions, while others perform more functions as they move from the farm to the consumer. Supply cooperatives are also these cooperatives sell farm supplies, (for example, seed, fertilizer, chemicals, and farm equipment) to their members. Service cooperatives are cooperatives that provide various services to their members. They also include organizations such as the farm credit system and other financial services to farmers. According to Chieochan et al (2000), the cooperatives promotion department of the Thai Ministry of Agriculture and Cooperatives, agricultural cooperatives perform the four main functions for members: - Provision of credit for the purchase of agricultural supplies and farm machinery. - Supply and sale of agricultural necessities and consumer goods. - Marketing of agricultural produce through local markets, provincial and national. - Provision of agricultural extension services.

\section{Importance of Agricultural Cooperatives}

Cooperative as a form of social organization, established with economic and business objectives. Its basic belief is that there must be a need to be satisfied for the members to form a cooperative or join an existing one. According to Agriculture for Impact (2020), Agricultural cooperative aims to increase members' production and incomes by helping better link them with finance, agricultural inputs, and information and output markets. It also helps farmers' benefits from economies of scale to lower their costs to acquiring inputs or hiring services such as storage and transport .enables farmers to improve product and service quality and reduce risks. They may also empower their members economically and socially by involving them in decision making processes that create additional rural employment opportunities and enable them to become more resilient to economic and environmental shocks. In general, agricultural cooperative's importance is broadly categorized as: Economic, Social, moral benefits, Educational, and Political benefits

In general, both the tangibility and intangibility nature of cooperatives make the benefits of cooperatives difficult to measure. With this regard, as stated by Barton (2000) farmers organize cooperatives with the objective to make greater profits, (i) by obtaining inputs and services at lower costs than they could get elsewhere or that were not available, and (ii) by marketing their products at better prices or in markets that were previously not accessible.

According to USDA (1990), the benefits of agricultural cooperatives to both farmer members and the general public include ownership and democratic control, improved service, increased farm income, quality of supplies and products, assured sources of supplies, improved farm management, lower production and marketing cost, expanded market, local leadership development, family farmer control of agriculture, stronger rural communities, enhanced competition and legislative support.

Development is one of the main goals that all communities try to achieve in order to improve the living standards for individuals in those communities (Mohamed, 2004). Agricultural cooperatives contribute an important role in rural development through the development of agriculture. The agricultural cooperatives are considered to be the most important organizations that pay attention to support the rural development in general and the agricultural development in special through the activities and services achieved for the sake of farmers (ibid).

The International Cooperative Alliance defines a cooperative as "an autonomous association of persons united voluntarily to meet their common economic, social, and cultural needs and aspirations through a jointly-owned and democratically-controlled enterprise" (ICA, 2010). Agricultural cooperatives have also taken steps to implement new strategies to enter the $21^{\text {st }}$ century (Prakash, 2000). Cooperatives are user-driven businesses that have contributed greatly to the development of one of the world's most productive and scientific-based agricultural systems. Cooperatives as distinct forms of business rely upon members to work together towards collective goals (Lasley et al., 1997). They have played an important role in strengthening market access and competitive returns for independent farm operators during the $20^{\text {th }}$ century. They adapted their operations to agricultural technological innovations, such as the use of fertilizers, plant and livestock breeding, agricultural mechanization, electricity and other new sources of energy, and to new information systems

\section{Historical Development of Agricultural Cooperatives in Ethiopia}

Cooperative is a worldwide movement that prevails in both developed and developing nations, and viewed as change agents in terms of social and economic developments. The change supposed to be brought by the cooperatives is not simple rather it needs rigorous work. Improved performance of agricultural cooperatives is assumed to have a role in fostering agricultural production activities and better resources allocation (Berhane, 2008).

In most developing countries including Ethiopia, agriculture is the most important economic activity in providing food, employment, foreign exchange and raw materials for industries. In the absence of an efficient agricultural sector, such countries severely suffer from the inability of feeding themselves and are likely to depend 
on food imports and food aid (Renee et al, 2000). Ethiopia is an agrarian economy based country where the agricultural sector plays an important role in the national economy, livelihood and socio-cultural system of the country. Therefore, agricultural sector is the foundation for the Ethiopian economy, and the overall economic growth of the country. Agriculture accounts for about 43\% of the country's Gross Domestic Product (GDP), 90\% of exports and 85\% of employment (ACSDS, 2012). Modern form of cooperatives started in Ethiopia during the reign of Emperor Haileselassie in 1960 and it was during this time that the modern cooperatives came in to existence in agriculture sector mainly to undertake commercial agricultural production for export purposes.

In connection to this, Alemayehu (2002) cited that the first cooperative legal action known as Decree number $44 / 1960$ was enacted for the establishment of agricultural cooperatives in the country. However, the overall performance of cooperatives was poor because of the undesirable conditions of the cooperatives to different limiting factors that include: requirements of land ownership and minimization of capital, insufficient supply of trained manpower, lack of access to market, dearth of membership training and education, and excessive government intervention. In 1974, Derg came to power and drafted and implemented different strategies including the expansion of cooperative societies. For the execution of this program, cooperative proclamation No. 138/1978 was declared with the aims of bringing socialist agriculture transformation and expansion of socialist marketing system in both urban and rural areas. The cooperative established under this proclamation were failed again because of wrong proclamation, problems encountered in implementing the proclamation, members wrong understanding on cooperatives and government interference in the functions of cooperatives (Birhanu, 2011).

During the mixed economy system followed by Derg, the cooperative movement had been getting retarded up to 1994. Then by the same year, the Transitional Government provided Proclamation No. 85/1994 for the establishment of cooperative societies that can play a great role in the free market. The responsibility given by Proclamation No. 85/1994 to promote and monitor agricultural cooperative societies was given to the Ministry of Agriculture and Regional Agriculture Bureaus. Since 1994, the government of Ethiopia has made efforts to promote new generation cooperatives that differ from their predecessors that were put in place under previous regimes. For its effectiveness, the constitution stated that this new type of cooperative should be based on the members' free will to organize, ability to fully participate in the free market and free of government intervention in their internal affairs (Proclamation No. 85/1994).

For example, Ethiopia's Sustainable Development and Poverty Reduction Program seeks to organize, strengthen and diversify autonomous cooperatives to provide better marketing services and serve as a bridge between small farmers and other non-farmers private sectors (Bernard et al., 2013). Since the improvements seen were very limited because of many reasons, the government has taken serious measures after 1996 to organize different types of cooperative societies under one umbrella by establishing cooperative promotion bureaus and registrar in each region. Then, Proclamation No. 147/1998 was established by the Federal Government for the establishment of cooperative societies that amended with Proclamation No. 402/2004 "Cooperative Societies (Amendment) Proclamation." It was under this proclamation that some improvements seen in cooperatives. Then, cooperatives have been started distributing inputs and giving loan to their members with the support of the government. Unions have also been organized and started to export some agricultural products (Birhanu, 2011).

As to the FCA (2011) report, there were 40,000 cooperatives in Ethiopia, of which approximately 10,000 are agricultural cooperatives. Currently, the numbers of primary cooperatives and cooperative unions are raised to 82,089 and 381 respectively. The same report from the meeting held at United Nations Economic Commission for Africa (UNECA) at Addis Ababa on $24^{\text {th }}$ January 2019 indicated that their capital is elevated to birr 20.5 billion or USD 722 million. Similarly, currently the members are grown from 3,642,602 in 2006 to 17,985,865 in 2019 (Desalegn, 2019).

\section{Roles of Agricultural Cooperatives in Ethiopia}

Cooperatives have also played an important role in rural communities, where they are an integral part of the social fabric. They encourage democratic decision making processes, leadership development and education (Prakash, 2000). Agricultural cooperatives have played an important role in the Ethiopian rural landscape for decades, and have become an integral part of its social structure. Cooperatives have contributed greatly to the development of modern national and systematized agricultural production-base, helped enhance self-sufficiency of major staple foods, and strengthened farmers' household economy by facilitating market access and competitiveness, adapting their operations to agricultural technological innovations and encouraging democratic decision-making processes, leadership development and education (Hermida, 2008). An agricultural cooperative is considered as one of the important economic and social organizations in rural societies. It plays an important role in the agricultural development through providing the farmers with production inputs, such as fertilizers, seeds and chemical substances, etc.

In general, cooperatives are playing an increasingly important role in economic growth, poverty reduction and democratization in Ethiopia. The justification provided by Emana \& Nigussie (2011) presumed that through distributing agricultural inputs, providing improved technologies, and encouraging farmers to produce high value 
crops, cooperatives in Ethiopia have been creating immense socio-economic benefits to both members and outsiders.

Besides, cooperatives are taking part in the distribution of improved seeds, farm implements (such as water pumps), pesticides and herbicides, modern beehives and other agricultural inputs. Evidence verifies that in the cropping period 2012/13, about 110,578.4 tons of improved seeds of different types were distributed by cooperatives (FCA, 2014b). Moreover, they also involve in distributing both quality and quantity nonagricultural input supplies such as construction materials, and consumable goods and also agricultural products at reasonable prices.

In serving as a market channel, cooperatives are also involved in output marketing and creating market opportunities. In doing so, they are achieving good results in the areas of coffee, sesame, grains, animal products, milk and milk products which they have effectively marketed. With this regard, empirical evidence provided by FCA (2014a) reveals that in the year 2007, seven coffee cooperative unions exported about 6,967 tons of coffee and generated revenue of about 24 million USD. This has elevated the export of coffee to 11,532 tons, which has enabled to generate about 76 million USD in 2013. Similarly, over the period of 2009 to 2013, on average cooperatives supplied about 2.5 million tons of grain; 11.7 million liters of milk; 124,404 live animals; 17,356 quintals of fish; and 21,141 quintals of honey per year to the market and improved members' income.

In addition, it holds guide symposiums for the farmers to acquire them with the necessary knowledge and skills about the agricultural new methods that aim at increasing the agricultural production and, therefore, promoting the rural society. Agricultural cooperatives also have a significant role of rural development and poverty reduction as well. All over the world, cooperatives play a major role in the agricultural and food industries in individual nation-states.

\section{Challenges of Agricultural Cooperatives}

In spite of the some progress mentioned above, cooperative movement during the last 50 years of its existence is not inspiring. Empirical evidence reveals that the cooperative movement in Ethiopia is facing several challenges. This sector is reliant on government for various reasons. There are also continuous government interferences, governance issues, accountability, legislative and policy support and new product development.

The great challenges of today and tomorrow are those of the internationalization of markets, of innovation, of environmental conservation and of food security. In the context of trade liberalization and globalization, the cooperative approach is regarded as one of the best instrument of self-protection for small farmers mainly due to its self-help concept and member's participation. The major challenges are the following:

$>$ Lack of adequate budget,

$>$ Lack of agricultural production requirements ( seeds - pesticides - fertilizers ) on time , quantity and prices suitable for farmers,

$>$ Disallowing cooperatives to contract directly to buy the requirements of production from agricultural companies and factories,

$>$ Lack of farmers trust in the agricultural cooperatives as a result of the low quality of services provided

$>$ Low participation of members and lack of awareness

$>$ Lack of Good Governance

$>$ Weak Linkage of Cooperatives with Stakeholders

\section{Conclusion and Proposed Interventions}

Cooperatives have played an important role in the development of agriculture in both developed and developing countries, which in turn have contributed in the socio-economic development of countries. It appears that many of these agricultural cooperatives are adapting their operations to the rapidly changing economic environment characterized by technological change, industrialization of agriculture and growing individualism. In Ethiopia, the success of agricultural cooperatives in the past was promoted because they served as agents of agricultural marketing boards and the Land Bank, which provided subsidized loans to commercial farmers. Small-scale farmers in the homelands did not have access to these cooperatives and their services for political reasons (Ortmann \& King, 2007).

Although cooperatives were established in the former homelands, many did not survive due mainly to poor management, lack of training, conflict among members and lack of funds. It is essential for agricultural cooperatives to remember that they should be attentive in inspiring, motivating and supporting its members as well in ensuring the sustainability of the production of their members.

Ultimately, the review recommends for promoting and developing the agricultural cooperative structure, which include:

$\checkmark \quad$ Implementing the cooperative principles and values. The cooperative structure should be independent from the government and the role played by the administrative body is only confined to supervising and directing without intervening in the activity or administration of the cooperatives. 
$\checkmark$ Allowing the cooperatives to import the agricultural production from abroad

$\checkmark \quad$ Allowing the cooperatives to contract and buy directly the requirements of production from factories or traders.

$\checkmark$ Providing financing necessary for the agricultural cooperatives,

$\checkmark$ Paying attention for holding the general assembly's on time as it is determined by law,

$\checkmark \quad$ Distributing the rest of surplus to the cooperative members as a return for them according to their dealing with the cooperative.

$\checkmark \quad$ Training leaders, board members, employees and managers of the cooperatives (Mohamed, 2004).

\section{References}

Aref, F. (2011). Agricultural Cooperatives for Agricultural Development in Iran. Life Science Journal; 8(1):82$85]$.

Cook, M. (1995). The future of US Agricultural Cooperatives: A Neo-Institutional Approach. American Journal of Agricultural Economics. 1153-1159. Cook, M., and Burress, M. (2009). A Cooperative Life Cycle Framework.

Cornforth, C. (2004). The Governance of Cooperatives and Mutual Associations: A Paradox Perspective. Annals of Public and Cooperative Economics, 75(1), 11-32.

Cropp, R. (2002). Historical Development of Cooperatives. Unpublished paper, Wisconsin Center for Cooperatives, University of Wisconsin-Madison, USA.

CSA. (2007). Summary and Statistical Report of 2007: The population and housing census, December 2008, Addis Ababa, Ethiopia.

Desalegn Fekadu (2019). The Role of Multi-Purpose Cooperatives in the Economic Development in Ethiopia, the Case of Lalo-Assabi District (West Wollega Zone, Oromia Regional State). Research on Humanities and Social Sciences. Vol.9, No.21, pp 13-30.

Dorward, A., Kydd, J., and Poulton, C. (2008). Traditional Domestic Markets and Marketing Systems for Agricultural Products. Background Paper for the WDR.

Emana, B. M. Nigussie (2011). Strategizing Cooperative Development in Ethiopia: an unpublished Report Submitted to Agricultural Transformation Agency (ATA). Addis Ababa, Ethiopia.

Ethiopian Agricultural Transformation Agency. (2014).

Federal Cooperative Agency (2014a).Cooperatives. Annual publication 1(11), Addis Ababa: FCA

Federal Cooperative Agency (2014b).Unpublished data, Addis Ababa, Ethiopia.

Federal Cooperative Agency. (2011, 2013 and 2014). Magazines Published by Public Relations Section. Addis Ababa, Ethiopia.

Fulton, M. (2001). Leadership in Democratic and Participatory Organizations. Canadian Journal of Agricultural Economics/Revue Canadienne D’Agroconomie, 49(4), 381-894.

Gebremadhin, E. (2006). Building Institutions for Markets: The Challenge in the Age of Globalization. Agricultural Development in Sub-Saharan Africa.

Gebremadhin, E. (2009). A Market for All Farmers: Market Institutions and Smallholder Participation.

Haileselassie Girmay. (2003). The Benefits of Cooperative Membership: A Cooperative Study in Saesie Tsaeda Emba District, Tigray, Ethiopia. Msc. Thesis, Submitted to Department of Food Business and Development, National University of Ireland, Cork.

Hansmann, H. (1999). Cooperatives Firms in Theory and Practice. LTA,48(4), 404-417.

Hoyt, A. (1989). Cooperatives in other countries. In Cooperatives in agriculture, ed. D. Cobia, 81-97. New Jersey, USA:

Ingalsbe, G., and Groves, FW. (1989). Historical Development. In Cooperatives in Agriculture, ed. D. Cobia, 106120. New Jersey, USA:

Meyer, R., and Larson, D. (1997). Issues in Providing Agricultural Services in Developing Countries. Promoting Third-World Development and Food Security, Luthr G. Tweeten y Donald McClelland (eds), Wstport: Praeger Publishers, 119-151.

Prentice-Hall, Inc. ICA, News. (1995). "Statement on the Co-operative Identity," No.5/6, http://www.coop. org/ica/info/ enprinciples.html: [Accessed on 28/11/2013].

Printice-Hall, Inc. Kijak Okok. (2013). The Effect of Large Agricultural Project on the Local People in Gambella Region (A Survey Study of Saudi Agricultural Development Project in Abobo Woreda), Mekelle University, (Unpublished Master Thesis). 